\title{
CLUSTER MODEL FOR EXTENSIVE GIANT TIGER SHRIMP (Penaeus monodon Fab.) TO PREVENT TRANSMISSION OF WHITE SPOT SYNDROME VIRUS
}

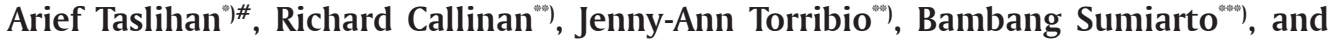 \\ Kamiso Handoyo Nitimulyo ${ }^{\text {*man }}$ ) \\ ") Main Center for Brackishwater Aquaculture Development, Jepara, Indonesia \\ ") University of Sydney, Australia \\ Faculty of Verinary Science, Gadjah Mada University, Yogyakarta, Indonesia \\ -maculty of Agriculture, Gadjah Mada University, Yogyakarta, Indonesia
}

(Received 22 December 2014; Final revised 27 March 2015; Accepted 8 June 2015)

\begin{abstract}
White spot syndrome virus (WSSV) has become epidemic in Indonesia and affecting shrimp aquaculture interm of its production. White spot syndrome virus is transmitted from one to other ponds, through crustacean, included planktonic copepode as carrier for WSSV and through water from affected shrimp pond. A cluster model, consist of shrimp grow out ponds surrounded by non-shrimp pond as a role of biosecurity has been developed. The model aimed to prevent white spot virus transmission in extensive giant tiger shrimp pond. The study was conducted in two sites at Demak District, Central Java Province. As the treatment, a cluster consist of three shrimp ponds in site I, and two shrimp ponds in site II, each was surrounded by buffer ponds rearing only finfish. As the control, five extensive shrimp grow out ponds in site I and three shrimp grow out ponds in site II, with shrimp pond has neither applied biosecurity nor surrounded by non-shrimp pond as biosecurity as well considered as control ponds. The results found that treatment of cluster shrimp ponds surrounded by non-shrimp ponds could hold shrimp at duration of culture in the grow out pond (DOC) 105.6 \pm 4.5 days significantly much longer than that of control that harvested at $60.9 \pm 16.0$ days due to WSSV outbreak. Survival rate in trial ponds was $77.6 \pm 3.6 \%$, significantly higher than that of control at $22.6 \pm 15.8 \%$. Shrimp production in treatment ponds has total production of $425.1 \pm 146.6 \mathrm{~kg} / \mathrm{ha}$ significantly higher than that of control that could only produced $54.5 \pm 47.6 \mathrm{~kg} / \mathrm{ha}$. Implementation of Better Management Practices (BMP) by arranging shrimp ponds in cluster and surrounding by non-shrimp ponds proven effectively prevent WSSV transmission from traditional shrimp ponds in surrounding area.
\end{abstract}

KEYWORDS: giant tiger prawn, extensive shrimp pond, shrimp pond biosecurity, cluster management shrimp pond

\section{INTRODUCTION}

In Indonesia and some others Asian countries, smallholder farmer take the largest proportion as shrimp aquaculture producer. Practice of extensive shrimp is typically very simple. Pond is prepared in very simple manner; water entering the pond without prior treatment as to eliminate pathogen and it's carrier, stock with low stocking density of 1 up to 5 Pl's.m ${ }^{-2}$, without aeration, almost no feed given to shrimp. Tiger shrimp is considered as the most

\# Corresponding: Main Center for Brackishwater Aquaculture Development, Jl. Pemandian Kartini, PO Box No. 1, Jepara, Jawa Tengah. Indonesia. Tel.: + (0291) 591125

E-mail: arieftaslihan@yahoo.com preferent species grown in extensive pond's because of traditional farmers have long experience with monodon. Shrimp is also take high priority in Indonesian aquaculture to get capital inflow, herein the government of Indonesia through Ministry of Marine Affairs and Fisheries put special attention to this commodity. Any actions to raise shrimp production has alrealy efforted, include production of good quality of seed, through broodstock selection programme for indigineus species, the tiger shrimp (Penaeus mondon Fab.) and importing of vannamei shrimp (Litopenaus vannamei).

White spot syndrome virus (WSSV) has the main pathogen affecting big loss in shrimp aquaculture up to present (Wongteerasupaya et al., 1995; 
Kasornchandra et al., 1998; Waikhom et al., 2006). Disease outbreak due to WSSV commonly occure during $1^{\text {st }} 2^{\text {nd }}$ month of growout period affecting mass mortality on shrimp, where shrimp size usually still very small and economically has no profit. As an epidemic area, source of WSSV presumably from shrimp ponds and surrounding waters, and seed come from hatchery that already infected. Extensive ponds lay out that usually lay side by side affecting disease transmission more easy either through carrier such as crabs (Waikhom et al., 2006); many species of shrimp (Hameed et al., 2002) that escape from one outbreak pond to neighbouring pond or water passing through the dike because of seepage. Virus release to water during pond outbreak has reported by many authors (Esparza-Leal et al., 2009; Hoa et al., 2011) to induce replicate outbreak to many ponds around affecting pond.

Management practices that has been formulated under scientific evident, promoted by FAO, that have been adopted worldwidely and proven effectively to reduce the risk due to disease in shrimp growout pond. However, adoption of practice has still low among farmers especially smallholder farmers. In some aspects adoption are limited due to lack of information, lack of capital among extensive shrimp farmers, farmer organization, and complication of the method (Corsin et al., 2007). Introducing better management practice (BMP) to shrimp smallholder farmers is required, however some modification of BMP protocols need to be considered to simplify the methods, to match with farmer's ability in relation to socioeconomic conditions, lack of farm infrastructure and limitation of available extension worker.

Objective of the study was to evaluate effectiveness of cluster shrimp surrounded by non-shrimp ponds as isolator to prevent WSSV transmission from extensive shrimp ponds neighbour.

\section{MATERIALS AND METHOD}

\section{Shrimp Growing Pond}

Shrimp ponds with variety size from 3.000 to $10.000 \mathrm{~m}^{2}$ were used in this study. The study was conducted in Demak District, Central Java Province. Before stock, pond bottom soil was prepared by drying for at least 7 days, tilting to expose $30 \mathrm{~cm}$ depth underneath soil to be oxygenated, liming until soil $\mathrm{pH}$ met criteria of standard quality for growing shrimp, which is above 5.5, and organic content reduced up to less than $12 \%$ (Chanratchakool et al., 1998). Before pumping water into the pond, water was pumping from inlet and screened using fine screen (mesh size $700 \mu \mathrm{m}$, green colour) to prevent introduction of wild crustacea and let settling in non-shrimp pond for minimum 3 days. Water media was then screened using finest screen (mesh size $300 \mu \mathrm{m}$, white colour) into shrimp growing ponds. When water colour has change to greenish, pond then stock with PCR screened post larvae stadia Pl $15-25$ at five $\mathrm{Pl}$ 's $/ \mathrm{m}^{2}$. Water quality was monitored during grow out periods such as dissolved oxygen, temperature, $\mathrm{pH}$, alkalinity, salinity, and water transparency by secchi disc. Water exchange were performed at maximum $10 \%$ / week to dilute water when phytoplantkon was become over bloom or when $\mathrm{pH}$ was fluctuated.

\section{Pond Location}

Five shrimp extensive ponds in the same area in site I (Figure 1) and three in site II (Figure 2) selected as control ponds. Control ponds were shrimp grow out pond operated as usually practices by farmer. Control pond was prepared as minimum standard, neither no drying nor tilting. Water was just pumped into ponds without prior screened. Stocking Pl's at density of 3-5 $\mathrm{pcs} / \mathrm{m}^{2}$ using non-PCR screened.

Shrimp health status based on field diagnose was monitored daily in line with water quality monitoring to observe any abnormal condition. When shrimp mortality was observed and increase drastically on the following days, that condition was judged as crash. White spots viral disease (WSVD) was diagnosed in either field observation, by looking at white patch on carapace and also confirmed by PCR in laboratory.

Indication of success from trial ponds was based on duration of culture (DOC in days), survival rate of shrimp within duration of culture, and occurence of WSDV (Corsin et al., 2007). Duration of culture, starting from postlarvae stock was accounted at least 90 days in growout pond without any disease symptom. Survival rate is how many shrimp still live during duration of culture divided by total stock time $100 \%$. Succesfull crop was determined when survival rate (SR) greater than $60 \%$. Statistical analysis based on ANOVA was performed in the study using program Excell.

\section{RESULT AND DISCUSSION}

\section{Culture Duration, Survival Rate, and Shrimp Production}

During disease outbreak, most of extensive ponds, do mature harvest less than 60 days, and survival rate was less than $30 \%$ due to WSSV. In this study, by implementing cluster system and introduction of non-shrimp ponds surrounding cluster shrimp pond, duration of crop was maintained at 105.6 \pm 4.5 days and significantly different at confident level 99\% 


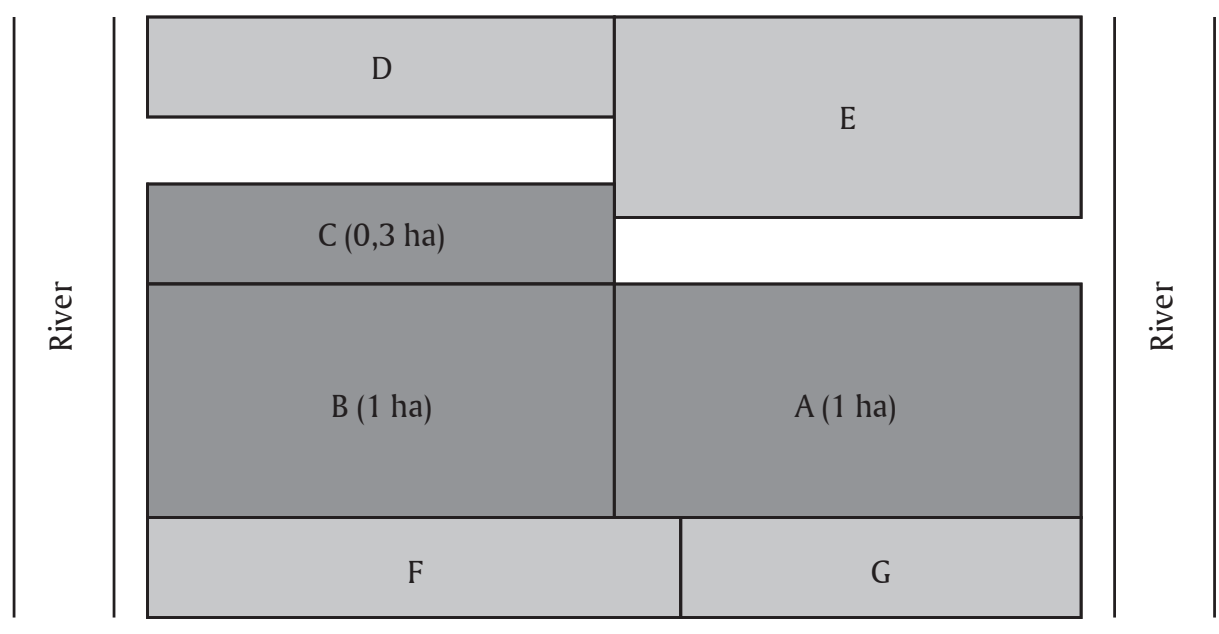

Remarks:

A, B , C = Shrimp pond; D, E, F, G = Non-shrimp pond role as WSSV isolator, was stocked with tilapia

Figure 1. Diagrammatic pond layout in site I, located at Sidorejo Village, Demak District. $\mathrm{ABC}=$ Shrimp grow out ponds, $\mathrm{DEFG}=$ Buffer ponds as biosecurity component

\begin{tabular}{|c|c|c|c|c|c|c|c|c|c|c|}
\hline & & \multicolumn{2}{|c|}{ Iskak } & \multicolumn{3}{|c|}{ K. Salim } & & & & \\
\hline \multirow{3}{*}{ Tarip } & \multirow[t]{3}{*}{ Sulkan } & \multirow{2}{*}{ C } & \multirow{2}{*}{ A } & \multicolumn{2}{|c|}{ G } & \multirow{2}{*}{ K. Salim } & \multirow{2}{*}{ Kaseri } & \multirow{2}{*}{ H. Siti } & \multirow{2}{*}{$\begin{array}{l}\stackrel{60}{E} \\
\stackrel{\Xi}{\Xi} \\
\dot{I}\end{array}$} & \multirow{2}{*}{$\begin{array}{l}\stackrel{b 0}{\Xi} \\
\stackrel{\Xi}{\Xi} \\
\text { !. } \\
I\end{array}$} \\
\hline & & & & B & $\mathrm{F}$ & & & & & \\
\hline & & & & \multicolumn{2}{|c|}{ E } & & & & \multicolumn{2}{|c|}{ H. Untung } \\
\hline \multicolumn{11}{|c|}{ River } \\
\hline
\end{tabular}

Figure 2. Trial site, located at site II at Serangan Village, Demak District. Remarks: AB = Grow out shrimp ponds, $\mathrm{CDEFG}=$ Buffer ponds stocked with tilapia and milkfish

and $95 \%$ compare to control at $60.9 \pm 16$ days. In control ponds, farmer harvest their pond due to WSSV outbreak (Table 1).

Survival rate in trial ponds also shown significantly higher than that of control ponds. In trial ponds average survival rate was $77.6 \% \pm 3.6 \%$ much higher and significantly different than that of control ponds that of $22.6 \pm 15.8 \%$. Shrimp production in trial pond also higher than that of control ponds. Average rate of shrimp production in BMP implementing ponds was $425.1 \pm 146.6 \mathrm{~kg} / \mathrm{ha}$ significantly different than that of control that only produced $54.5 \pm 146.6 \mathrm{~kg} / \mathrm{ha}$. Higher of shrimp production in BMP ponds are either due to higher survival rate and duration of culture.

High production and survival rate achieved in the treatment ponds may due to availability of non-shrimp ponds surrounding cluster shrimp ponds that halt WSSV transmission from surrounding traditional ponds. Local pond with no biosecurity measure are vulnerable for disease transmission from the surrounding traditional shrimp ponds, resulting in outbreak more early, with low production due to low survival rate of shrimp.

\section{Water Quality Monitoring of The Pond}

Water quality was monitored during implementation of the research to observe some unusual trend that may affect on shrimp (Table 2). Fluctuation of some parameters also be analysed whether it is suitable for shrimp.

As general temperature during culture periods was still in the optimal range. In the morning, lowest temperature was $23.4^{\circ} \mathrm{C}$, and the afternoon the highest 
Table 1. Average duration of culture (DOC) on cluster and biosecurity (BMP) compare to control pond (non-BMP)

\begin{tabular}{lcc}
\hline \multicolumn{1}{c}{ Parameters } & BMP & Non-BMP \\
\hline DOC (days) & $105.6 \pm 4.5^{* * *}$ & $60.9 \pm 16.0$ \\
Survival rate (\%) & $77.6 \pm 3.6^{* * *}$ & $22.6 \pm 15.8$ \\
Production (equivalent $\mathrm{kg} / \mathrm{ha})$ & $425.1 \pm 146.6^{* * *}$ & $54.5 \pm 47.6$ \\
\hline
\end{tabular}

") Stocking density at 3-5 shrimp/ $/ \mathrm{m}^{2}$; ") Significantly different at 95\% and 99\% confident level

Table 2. Water quality monitoring during grow out

\begin{tabular}{|c|c|c|c|c|c|c|c|}
\hline & & & \multicolumn{5}{|c|}{ Pond site } \\
\hline \multicolumn{3}{|c|}{ Parameters } & \multicolumn{2}{|c|}{ Serangan } & \multicolumn{3}{|c|}{ Sidorejo } \\
\hline & & & A & B & A & B & $\mathrm{C}$ \\
\hline \multirow{3}{*}{ Salinity (g/L) } & & Minimum & 18 & 17 & 7 & 7 & 15 \\
\hline & & Maximum & 41 & 42 & 15 & 15 & 21 \\
\hline & & Mean $\pm S D$ & $26.6 \pm 6.7$ & $27.9 \pm 7.2$ & $14.2 \pm 1.8$ & $14.2 \pm 1.8$ & $15.5 \pm 1$ \\
\hline \multirow{6}{*}{ Temperature $\left({ }^{\circ} \mathrm{C}\right)$} & Morning & Minimum & 23.6 & 23.4 & 24 & 24 & 24 \\
\hline & & Maximum & 27.3 & 28.4 & 27 & 27 & 27 \\
\hline & & Mean $\pm S D$ & $26.3 \pm 0.9$ & $26.3 \pm 1$ & $25 \pm 1$ & $25 \pm 1$ & $26 \pm 1$ \\
\hline & Afternoon & Minimum & 27.5 & 27.1 & 28 & 28 & 28 \\
\hline & & Maximum & 32.6 & 32.9 & 31 & 31 & 32 \\
\hline & & Mean $\pm S D$ & $30.4 \pm 1.0$ & $30.4 \pm 1$ & $29.8 \pm 0.7$ & $29.8 \pm 0.7$ & $30 \pm 0.6$ \\
\hline \multirow{6}{*}{$\begin{array}{l}\text { Dissolve oxygen } \\
(\mathrm{mg} / \mathrm{L})\end{array}$} & Morning & Minimum & 1.84 & 1.43 & 1.6 & 1.6 & 2.3 \\
\hline & & Maximum & 4.45 & 4.46 & 5.6 & 5.6 & 5.1 \\
\hline & & Mean $\pm S D$ & $2.9 \pm 0.5$ & $2.9 \pm 0.5$ & $3.8 \pm 0.7$ & Not analysed & $3.5 \pm 0.7$ \\
\hline & Afternoon & Minimum & 1.89 & 1.97 & 2.7 & Not analysed & 4.2 \\
\hline & & Maximum & 8.59 & 6.67 & 11.2 & Not analysed & 12.2 \\
\hline & & Mean $\pm S D$ & $5.26 \pm 1.4$ & $5.6 \pm 1.6$ & $7.3 \pm 2$ & Not analysed & $6.82 \pm 1.7$ \\
\hline \multirow{6}{*}{$\mathrm{pH}$} & Morning & Minimum & 6.9 & 7.1 & 8.5 & Not analysed & 8.3 \\
\hline & & Maximum & 7 & 8.6 & 9.3 & Not analysed & 9.1 \\
\hline & & Mean \pm SD & $8.6 \pm 0.4$ & $5.8 \pm 1.6$ & $8.8 \pm 0.2$ & Not analysed & $8.8 \pm 0.2$ \\
\hline & Afternoon & Minimum & 7.2 & 7.4 & 8.8 & Not analysed & 8.6 \\
\hline & & Maximum & 8.9 & 8.6 & 9.8 & Not analysed & 9.5 \\
\hline & & Mean $\pm S D$ & $8.8 \pm 0.4$ & $7.8 \pm 0.4$ & $9.3 \pm 0.3$ & Not analysed & $9.2 \pm 0.3$ \\
\hline
\end{tabular}

temperature was $32.9^{\circ} \mathrm{C}$. The lowest temperature was recorded during the middle of culture. Given the range of temperature, as average measurement, assumed that temperature was suitable for shrimp. Many author considered that outbreak usually followed by mass mortality was due to temperature drop less than $25^{\circ} \mathrm{C}$ (Rahman et al., 2007). The onset of outbreak was due to virus multiplicate more fast in low temperature.

Dissolved oxygen during culture in site II was more fluctuated than site I. Difference in DO may due to different algae growth in the two locations, where in site II was dominated by phytoplankton, while in site I dominated by seeweed (macroalgae). Concentration dissolved oxigen in the morning was between 1.6 and $5.6 \mathrm{mg} / \mathrm{L}$ and in the afternoon between $1.89 \mathrm{mg} /$ $\mathrm{L}$ and $12.2 \mathrm{mg} / \mathrm{L}$ in site I. Macro algae seem to give better condition in the ponds rather than phytoplankton.

Daily fluctuation of $\mathrm{pH}$ was less than 0,5 either in site I or site II. High fluctuation was observed in the middle of culture period. Average $\mathrm{pH}$ at site II was 
relatively lower than that of in site $\mathrm{I}$. At site I lowest $\mathrm{pH}$ in the morning is 8.4, and highest $\mathrm{pH}$ is in afternoon at 9.6. At site II, lowest $\mathrm{pH}$ is in the morning at 7 and highest is in the afternoon at 8.8.

In general water quality in BMP trial ponds, was considered represent pond condition in local area. Soil $\mathrm{pH}$ at average was considered as good and suitable for shrimp grow out. Texture soil that was silty clay represented of normal soil and good for construction and relatively impermeable. Water quality such as salinity in ponds was considered in optimal range that of within range of 15-25 ppt. Average dissolved oxygen in the morning is $2.9-3.8 \mathrm{mg} / \mathrm{L}$, and in afternoon 5.3-7.3 mg/L. Dissolved oxygen was considered as limiting factor for aquatic organism. However in this research, dissolved oxygen is beyond of suitable range for monodon.

\section{Effectiveness of Cluster System of Shrimp and Biosecurity Model}

Transmission of disease in shrimp farming areas generally occur in succession, one pond get disease outbreak, a few days later the pond next to affected pond get outbreak. The WSSV transmitted from affected pond to other neighbour ponds mainly by water seepage route. Transmission through water has been presented by Flegel (1997). Kautsky et al. (2000) considered spreading pathogen in shrimp aquaculture based on ecological perspective, relevant to densities of shrimp grow out activities in farm, as when pond densities was high the of trend of WSSV being spread was also high.

In this study, the application of biosecurity in extensive shrimp ponds by surrounding shrimp ponds as cluster, and by non-shrimp ponds function as isolator proven effectively prevent pathogen transmission from surrounding traditional shrimp pond. The biosecurity model implemented in this study could successly maintained shrimp until 110 days without any sign of WSSV infection at site I and 102 days for pond at site II. The length of culture duration was much longer than average the ponds in the local farm area vicinity, which are only could survive until 57 days. Most of ponds in the vicinity of the study harvest premature due to WSSV outbreak. The presence of surrounding non-shrimp ponds to shrimp ponds have effectively reduce disease transmission, or delaying the onset of disease from the affected extensive shrimp ponds surrounding the trial ponds.

Monitoring WSSV by field diagnose and further PCR analysis revealed no WSSV was detected in shrimp sample taken from trial ponds. Meaning that shrimp in grow out was considered free of WSSV at detection limit for conventional PCR. In this study, there was no attempt to quantify prevalence in shrimp population in ponds for WSSV. Sample was taken purposively, as much as six shrimp shown weak was selected as sample for further analysis using PCR. Cluster model introduced in this study may become a solution to solve WSSV problems in shrimp farming, while there are no other measure effectively control WSSV (Sanchez-Martinez et al., 2007).

Occurence of non-shrimp pond surrounding shrimp grow out pond considered as isolator. Non-shrimp ponds also provided space to prevent entering wild crab, planktonic copepods that acting as carriers (Waikhom et al., 2006) into cultured shrimp. Occurence of non-shrimp pond in this trial was also to prevent any seepage of water from affected pond in surrounding trial intro shrimp pond, due to water is also considered as media for WSSV transmission (Chou et al., 1998; Wu et al., 2001). Non-shrimp pond plays important role in preventing carriers and water directly to neighbouring shrimp pond, in order to prevent shrimp grow out pond from being transmitted by WSSV from extensive shrimp ponds. This was an effective way to achieve success in shrimp farming. However it's difficult in it's application in extensive ponds in Indonesia, because ownership of land by farmers are limited. The farmers generally only have one or two ponds, making difficult to implement the whole system, such as providing buffer ponds if they implement individually. However the cluster system can be implemented if farmer work in cooperative with other farmers. Farmers can arrange their ponds into cluster for ponds growing shrimp, then selecting which ponds belongs to member use as buffer that grow only finfish. Farmer's pond selected as buffer pond can receive compensate from other farmer. Some economic value finfish can be selected such as tilapia, milkfish, rabbit fish or barramundi. Occurence of finfish in buffer pond has also very important as it could act as biofilter to eliminate escaping shrimp or mysid into shrimp growing ponds in the cluster.

Any efforts are still needed to explore the potential of fish species that can be cultivated as an alternative to shrimp into buffer ponds. By cultivating economically profitable finfish, farmers have choise to culture finfish in their ponds and become buffer to prevent spread of WSSV to shrimp grow out ponds. This study also an effort to convert the International Principles for Responsible Shrimp Farming into practice like those already considered by Corsin et al. (2007).

\section{CONCLUSION}

Arrangements of shrimp ponds into cluster, surrounded with non-shrimp ponds has proven effectively 
prevent WSSV transmission in WSSV epidemic area. Non-shrimp pond have role as isolator, to halt WSSV carried out by carrier or water from surrounding into cluster shrimp ponds. Effectiveness of the cluster are supported by members of cluster. The member should discipline and commited with agreement in the group of cluster such as pond should stock with good quality and health of shrimp fry, and shouldn't restock during crop.

\section{AKNOWLEDGMENT}

The research was funded by ACIAR through grant no. FIS2005/169. Special thank to Dr. Richard Callinan, researcher from University of Sydney for valuable suggestion during trial process, Supito, Iwan, Deni, and farmers who assist and involved in this work.

\section{REFERENCE}

Esparza-Leal, H., Escobedo-Bonilla, C.M., CasillasHernandez, R., Alvarez-Ruiz, P., Portillo-Clark, G., Valerio-Garcia, R.C., Hernandez-Lopez, J., MendezLozano, J., Vibanco-Perez, N., \& Magallon-Barajas, F.J. (2009). Detection of white spot syndrome virus in filtered shrimp-farm water fraction and experimental evaluation of its infectivity in Penaeus (Litopenaeus) vannamei. Aquaculture, 292, 16-22.

Chanratchakool, P., Thurnbull, J.F., Funge-Smith, S.J., MacRae, I.H., \& Limsuwan, C. (1998). Health management in shrimp ponds. $3^{\text {rd }}$ Edition. Aquatic Animal Health Research Institute, Bangkok.

Chou, H.Y., Huang, C.Y., Wang, C.H., Chiang, H.C., \& Lo, C.F. (1995). Pathogenicity of baculovirus infection causing white spot syndrome in cultured penaeid shrimp in Taiwan. Dis. Aquat. Org., 23, 165-173.

Corsin, F., Giorgetti, G., \& Mohan, C.V. (2007). Contribution of science to farm-level aquatic animal health management. In Dodet, B. The OIE Scientific \& Technical Department (Eds. The OIE Global Conference on Aquatic Animal Health, Dev. Bio (Basel). Basel, Karger, 129, 35-40.

Flegel, T.W. (1997). Special topic review: Major viral diseases of the black tiger prawn (Penaeus mono- don) in Thailand. World Journal of Microbiology $\mathcal{E}$ Biotechnology, 13, 433-442.

Hameed, A.S., Murthi, B.L.M., Rasheed, M., Sathish, S., Yoganandhan, K., Murugan, V., \& Jayaraman, K. (2002). An investigation of Artemia as a possible vector for white spot syndrome virus (WSSV) transmission to Penaeus indicus. Aquaculture, 204, 1-10.

Hoa, T.T.T., Zwart, M.P., Phuong, N.T., Vlak, J.M., \& de Jong, M.C.M. (2011). Transmission of white spot syndrome virus in improved-extensive and semi-intensive shrimp production systems: a molecular epidemiology study. Aquaculture, 313, 7-14.

Kasornchandra, J., Boonyaratpalin, S., \& Itami, T. (1998). Detection of white spot syndrome in cultured penaeid shrimp in Asia, microscopic observation and polymerase chain reaction. Aquaculture, $164,243-251$.

Kautsky, N., Ronnback, P., Tedengren, M., \& Troell, M. (2000). Ecosystem perspectives on management of disease in shrimp pond farming. Aquaculture, 191, 145-161.

Rahman, M.M., Corteel, M., Dantas-Lima, J.J., Wille, M., Alday-Sanz, V., Pensaert, M.B., Sorgeloos, P., \& Nauwynck, H.J. (2007). Impact of daily fluctuations of optimum $\left(27^{\circ} \mathrm{C}\right)$ and high water temperature $\left(33^{\circ} \mathrm{C}\right)$ on Penaeus vannamei juveniles infected with white spot syndrome virus (WSSV). Aquaculture, 269, 107-113.

Sanchez-Martinez, J.G., Gabriel Aguirre-Guzman, G., \& Mejia-Ruiz, H. (2007). White spot syndrome virus in cultured shrimp: a review. Aquaculture Research, 38, 1339-1354.

Wongteerasupaya, C., Vickers, J.E., Sriurairalana, S., Nash, G.L., Akarajamorn, A., Boonsaeng, V., Panyim, Tassnakajon, A., Withyachumnarnkul, B., \& Flegel, T.W. (1995). A non-occluded, systemic baculovirus that occurs in cells of ectodermal and mesodermal origin and causes high mortality in the black tiger prawn, Penaeus monodon. Dis. Aquat. Org., 21(2), 69-77. 